\title{
The Study of Marl Soil Potential in Electricity Generation
}

\author{
Pakpoom Chansri, Bamrung Changthong, and Padhetpoom Angintarasong \\ Industrial Technology Program, Faculty of Industrial Education and Technology \\ King Mongkut's University of Technology Thonburi \\ Bangkok, THAILAND, 10140 \\ E-mail: pakpoom.cha@kmutt.ac.th
}

\begin{abstract}
Currently, the demand for energy is increasing. We are the focus renewable energy source, as Lopburi, Thailand because Lopburi has a lot of marl soil. This project study about potential of marl soil to produce electricity by using different pool rod the cathode $(+)$ and anode $(-)$ into marl. It's may affect the oxidation reaction at the cathode, and reduction of the anode cause voltage. The experiment results were mixed vinegar with marl, using copper and zinc rods show the best result, which the voltage is $1.09-\mathrm{V} /$ cell, when $\mathrm{pH}$ was decreased temperature increased. When tested with the result current up to $3 \mathrm{~mA} / \mathrm{cell}$. The phone battery charging is $12.72 \mathrm{~V}, 140.8 \mathrm{~mA}$ in 4.5 hours. A mineral marl soil test, after test found that Ferric, Potassium, Aluminum and Silica were gone. Thus, the result shown that the electricity that produce form marl soil can be use with low power load such as LED load, phone battery charging etc.
\end{abstract}

\section{Index Terms - Cathode / anode / oxidation / reduction.}

\section{INTRODUCTION}

Currently, power sources have been escalated rapidly requirement in a moment, which power source use to produce electricity is reduced. For instant, gas, mineral and heat underground might not sufficient to support additional requirements for producing electricity in the future. So, we have to find new sources or new substitute sources to reduce using main power sources [1].

The energy from soil used to produce electricity, although not sufficient to meet demands for electricity. The energy can reduce their dependence on primary energy. However, earth soil chemical reactions and electron affinity based earth batteries may be explored for low to high voltage DC potential to drive small scale white emission LED lighting loads in remote hilly areas or small scale electronic devices [2]. They can also be considered to replace high voltage low current charging power supplies or ionization power supplies [3-4].

Marl is friable soil. It's substantive component is calcium carbonate $\left(\mathrm{CaCO}_{3}\right)$. It comes from Limestone debris. In general condition, find them next to limestone. The major source in Thailand is found at Tambol Thasala, Lopburi province. Marl is chemical base uses in generally cement production, agriculture, use to reduce an acid in soil as well as alkaline, Future more, it is use widely to solve an acid soil.
However, the problems encountered in the production of electricity from the soil [2] are a small charge of electricity which needs to increase the power of the original. This study is use soil to produce electric current to produce of soil. It has specific gravity and moisture of soil changed. The output voltage achieved from common materials.

In this experiment, the proposed of this study is to design and study battery power source base of marl soil to be generated electricity. For a study factor charge and discharge column voltage of marl soil and application used low power load such as LED lighting load, clock battery load and mobile battery charger load, etc.

\section{ERATH BATTERIES SYSTEM}

\section{A. Erath Battery}

Erath battery is a battery power produce from soil which can generate electricity. The different metal sheets cathode and anode put into soil to the oxidation reaction at the cathode, and reduction of the anode to produce voltage. It cans charge from soil are shown in Table 1. [2]

TABLE I. Potential of Common Metals SheEt Suitable For Earth BATTERY

\begin{tabular}{|c|c|c|c|c|}
\hline \multicolumn{2}{|c|}{ Anode materials } & \multicolumn{2}{c|}{ Cathode materials } & Battery \\
\hline Materials & $E^{9}(\mathrm{~V})$ & Materials & $E^{9}(\mathrm{~V})$ & Volts \\
\hline Magnesium & -1.75 & Coke & +0.30 & 2.05 \\
Zinc & -1.10 & Graphite & +0.30 & 1.40 \\
Zinc & -1.10 & Copper & +0.20 & 0.90 \\
Aluminum & -0.80 & Carbon & +0.30 & 1.10 \\
Iron & -0.50 & Coal & +0.30 & 0.80 \\
\hline
\end{tabular}

The material with higher capacity can absorb more tightly to the pole. Therefore, the nutrient management of plant, soil is not only. The concentration of nutrient ratio was the most significant to evaluate the soil nutrient fertility. It has method measuring the value of the Cation Exchange Capacity (CEC) or the capacity to exchange ions percent saturation of the $\mathrm{pH}$. The ratio of concentrations is between nutrients in form of ions or ion with earth battery of the same size to be different.

The CEC or the capacity to exchange ions can be used as a measure for the size of the earth battery capacity or means to contain nutrients. The energy of the soil battery is clay which has organic matter or high humus is very likely that the CEC 
high ground even with the CEC are the buffer is to be able to charge or energy. The CEC is positive such as; calcium, magnesium, potassium, and sodium are exchange which can be absorbed into the surface of the nth particle, or by measuring the CEC of the soil.

The chemistry will be measured out to be milli-equivalents per 100 grams (meg/100g) by the value of each of the ionexchange capacity (CEC) electrolytes with different conductivity. Usually, the battery will not work unless we fill the water alone, but must have the power to make acid cause to current.

\section{B. Marl Soil}

The marl soil have chemical composition is calcium carbonate or clay-rich mudstone with calcareous clay mineral composition variability of clay and aragonite. Most of the objects are the main components of the mixture between soil clay and calcium carbonate, the conditions under which the water is the soil contains mineral clay, 65 percent and carbonate 65-35 percentage used as the soil is acidic to neutral conditions, the incoherent light and the soil is composed of calcium carbonate clay and silt-sized sediment. It was found to be the primary fresh water environments in shown Fig. 1.

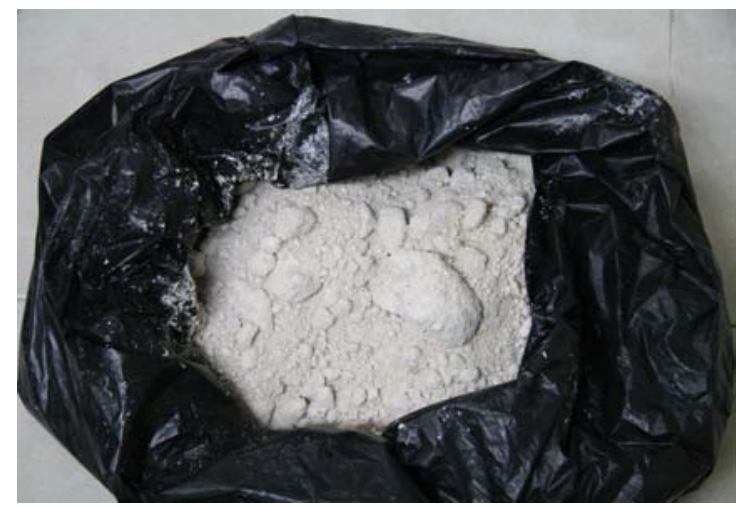

Fig. 1. Example of marl soil.

The CEC of marl soil is 8.25. It has the effect of reaction on the cathode - anode. But, it's rare mineral nutrients in marl. A marl soil is component in shown Table 2.

TABLE II. ANALYSIS OF THE CEC OF THE MINERAL MARL.

\begin{tabular}{|c|c|c|c|c|c|}
\hline \multicolumn{3}{|c|}{ Anode materials } & \multicolumn{3}{c|}{ Cathode materials } \\
\hline Materials & Ions & $\%$ CEC & Materials & Ions & $\%$ CEC \\
\hline Nitrogen & $1-$ & - & Magnesium & $2+$ & 12.05 \\
Phosphorus & $3-$ & - & Calcium & $2+$ & 29.89 \\
Chlorine & $2-$ & - & Sodium & $1+$ & 1.5 \\
Sulfur & $1-$ & - & Hydrogen & $1+$ & 1.5 \\
Aluminum & $1-$ & - & Silica & $2+$ & 9.45 \\
Manganese & $2-$ & 0.98 & Potassium & $2+$ & 13.8 \\
& & & Zinc & $2+$ & - \\
\hline
\end{tabular}

\section{EXPERIMENTAL SETUP}

The experimental study was the power of marl soil. The study of the physical properties and the chemistry of marl soil are affecting the chemical reaction cause causes oxidation to the metal anode and cathode to result in the highest voltage. The electrode marl soil reaction voltage $1.09-\mathrm{V}$ may be used to drive small scale lighting and electronic loads. Outside on bare earth the currents and voltages were found higher at smaller distances and lower at relatively larger distances between cathode and anodes. The voltages and currents readings were found unstable on the digital multi-meter. Repetition of above experiment with interchange of electrodes from north to south resulted in relatively increased voltages and currents.

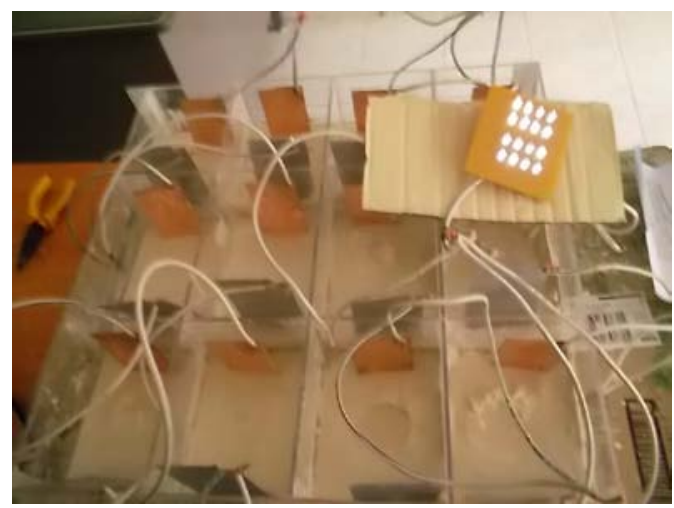

Fig. 2. Example of pickup twelve cells 12.79V/140.8mA earth battery.

In shown Fig. 2 is conductor of the cathode and anode into the prepared pickup container. In the experimental, the load LED lamp. This will bring light LED 70mA, 16 LED to come to the 4-parallel 4 rows as shown in Fig. 1 with the pickup channel 12 by the series cells 12 channels of $12-\mathrm{V}$.

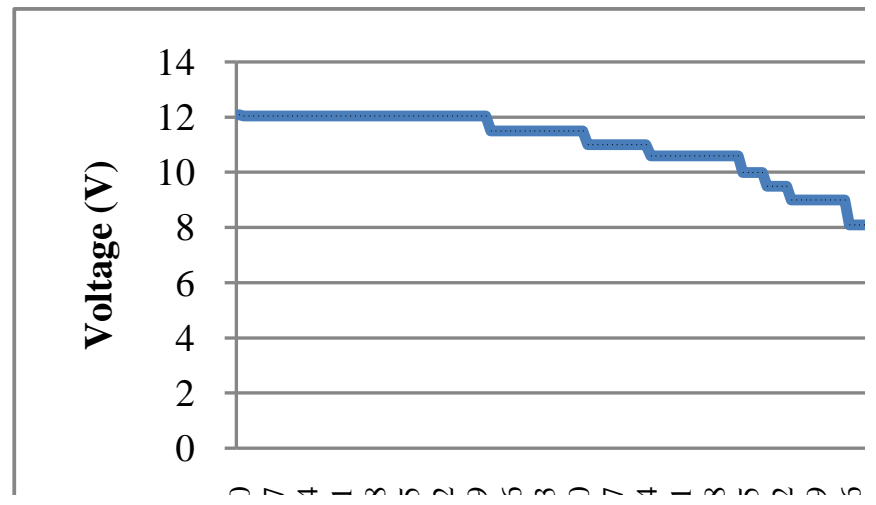

Fig. 3. The voltage output of earth battery to LEDs load.

In shown Fig. 3 is a measure of the voltage of the LED lamps found inertial voltage at $12.79-\mathrm{V}$ in voltage constant average is about 48 hours of bright light LEDs. Then, the voltage drop in the time 40-45 hour's LED lamps less bright, but will be take voltage LEDs last up to 184 hours of LED lamps are goes out. 


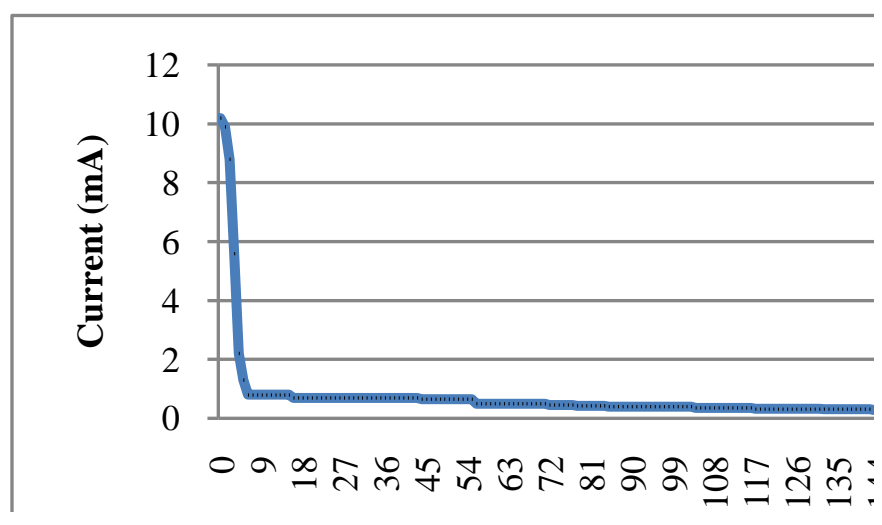

Fig. 4. The current output of earth battery to LEDs load.

In Fig. 4 is relatively between current can be current start at $10.20 \mathrm{~mA}$ and decreased $1 \mathrm{~mA}$ during 8 hours because a current form soil is low and low surface are for the ion exchange oxidation and reduction that cause low electricity.

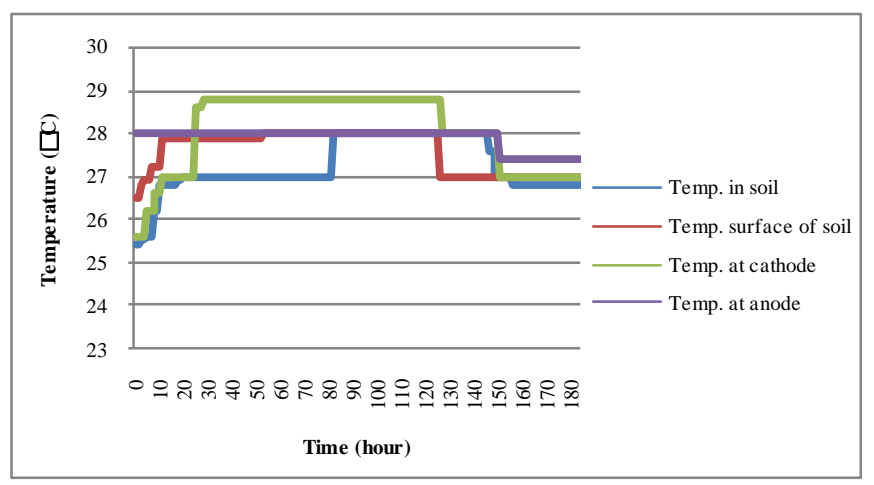

Fig. 5. The parameter temperature of earth battery to LEDs load.

In Fig. 5 is the experimental analyses parameter of fourpoint temperature are the temperature in soil, surface of soil, near the anode, and near the cathode. The result of voltage on the LEDs load from cathode is slightly higher than room temperature. The temperature at the cathode has high temperature because due to the transfer of ions cause the oxide near the cathode.

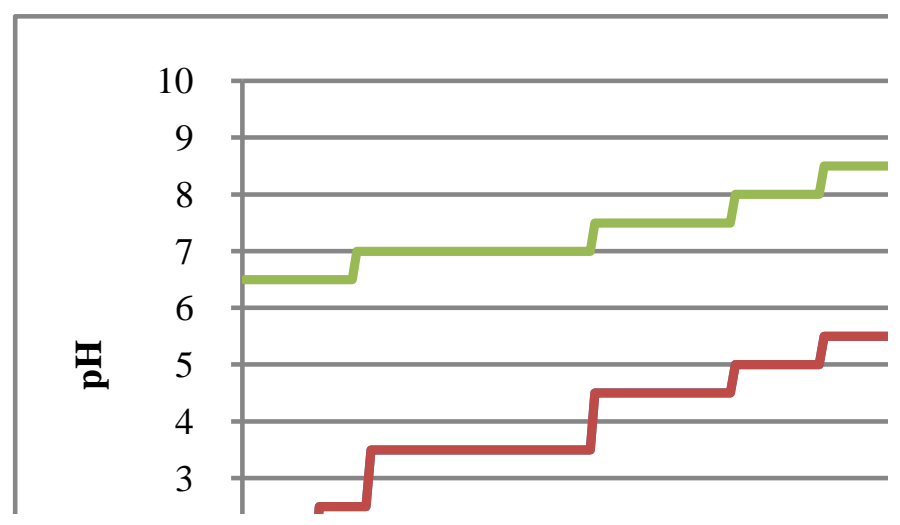

Fig. 6. The parameter $\mathrm{pH}$ of earth battery to LEDs load.
The experimental result of $\mathrm{pH}$ value in shown Fig.6 when take the LEDs load found the $\mathrm{pH}$ marl soil at the cathode has than anode $(\mathrm{pH}=1.5)$. It causes the sulfur oxide and bubbles around the anode and the cathode Fig. 7, show the LEDs load in period of time $\mathrm{pH}$ value of in near the cathode and anode are increase. The $\mathrm{pH}$ is change to more than $7(\mathrm{pH}>7)$.

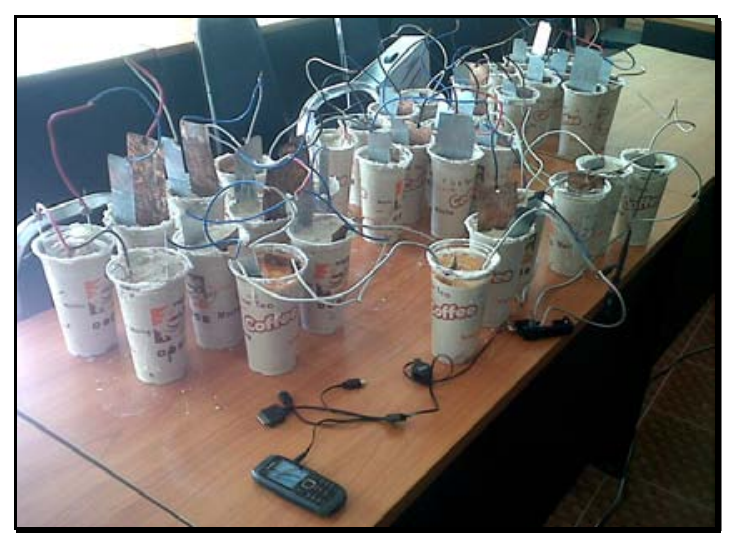

Fig. 7. Experimental of a charge mobile battery.

In the experiment of charge mobile battery pack of marl soil (In shown Fig. 6) found that the voltage used to charge mobile phone battery at $12.39 \mathrm{~V}, 140.8 \mathrm{~mA}$. The voltage measurement is supplied to the battery on a mobile phone to $2.94 \mathrm{~V}$ and a rapid decline. Therefore, they can itself generate voltage form marl soil to charge the handset battery pack. It takes about 10 seconds which used time in charging 3 hours full battery shown in Fig. 8.

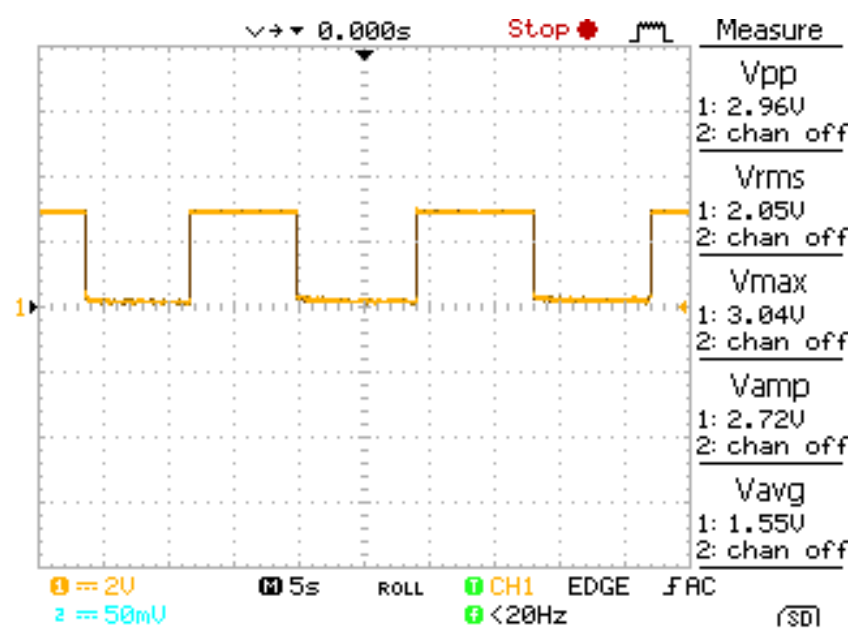

Fig. 8. Experimental of a waveform charge mobile battery.

\section{CONCLUSION}

The result of this experimental show that size test conductors affect the high voltage on the copper and zinc are equal that the maximum and constant voltage is 1.09 volts per cell. The earth batteries per cell are series 12 cells to be voltage $12.79-\mathrm{V}$ supply to the load. The LEDs light with load have longer usage. Temperature is at the conductor is rise. The temperature in soil is increase and a $\mathrm{pH}$ as weak acid and 
alkaline mineral in the marl soil test analysis was used. And, after the experiment found showed element damaged are silica, ferric, aluminum, and potassium. The CEC is 8.25. Advantage of earth batteries from marl soil has shown reasonable potential for use in remote locations for signaling as well as charging cell phone and white light illumination applications, but disadvantage is low power. Further, we are test charger voltage into marl soil for a study behavior of the soil which has changed increase ions in soil.

\section{ACKNOWLEDGMENT}

This work has been supported by Department of Agriculture, Lopburi, Thailand and Department of Alternative Energy Development and Efficiency, Ministry of Energy. The Authors would like to acknowledge comment's Prof. Narong Mungkung at King Mongkut's University of Technology Thonburi.

\section{REFERENCES}

[1] Gish, O. H., "The Natural Electric Currents in the Earth's Crust", The Scientific Monthly, vol. 32. pp. 5-2, 1989.

[2] N. Khan, Z. saleem, and N. Abas, "Experimental Study of Earth Batteries", ICEE2008 Second International conference on Electrical Engineering, pp.1-4, March 2008.

[3] Ryeczek, "U.S. Patent 4,457,988 Earth battery”, July 3, 1984.

[4] Daniel Drawbaugh, "U.S. Patent 211,322 Earth battery for electric clocks", January 3, 1897.

[5] E. Katz, "Alexander Bain”, The history of electrochemistry, electricity and electronics; Biosensor \& Bioelectronics
[6] R. J. Edward, "Measurement of Soil Resistivity \& Calculation of Earth Electrode Resistance” February 1998. 